\title{
Developing Sosiocultural Base Thematic-Integrative Learning Instrument for Elementary School Students
}

\author{
Slamet Arifin \\ Teachers Elementary School Education Program, The Faculty of Teachers Training and Education, \\ Universitas Kuningan. Jalan Pramuka No. 67 Kuningan Jawa Barat, 45511, Indonesia. \\ Email: slamet.arifin@uniku.ac.id \\ Received: 16 June 2017; Revised:3 July 2017; Accepted: 26 July 2017
}

\begin{abstract}
This study aimed at: (1) generating sociocultural base-thematic-integrative learning instrument on the theme "My Aspiration" for the students of SD N Pujokusuman 1; and (2) identifying the effectiveness of the sociocultural base-thematic-integrative learning instrument on the theme "My Aspiration". This study referred to the steps that had been developed by Borg \& Gall. The developmental design was categorized into three procedures which consisted of: (a) preliminary stage; (b) development stage; and (c) testing stage. The subjects of the main experiment were 28 elementary school students. Then, the subjects of the operational test were 84 students from SDN Pujokusuman 1. The subjects of operational product test in the experimental group were 56 students and in the control group were 28 students. In gathering the data for this study, the researcher employed interview guideline, learning instrument product assessment sheet, teacher's checklist observation sheet, student's checklist observation sheet, learning results test, and teacher's response questionnaire. In conducting the data analysis, the researcher made use of independent sample t-test with the rate of significance 0.05 . The results of the study show that the learning instrument belongs to the "Good" category. The implementation of the learning instrument, in general belongs to the "Very Good" category. However, there are differences between the control group and the experimental group after the implementation of the sociocultural based-thematic-integrative learning instrument with $\mathrm{p}<0.05$. There is also significant improvement with $\mathrm{p}=0.0001$.
\end{abstract}

Keywords: learning instrument, thematic-integrative, sociocultural base-learning

How to Cite: Arifin, S. (2017). Developing sosiocultural base thematic-integrative learning instrument for elementary school students.Jurnal Prima Edukasia, 5(2), 186-192. doi:http://dx.doi.org/10.21831/jpe.v5i2.14510

Permalink/DOI: http://dx.doi.org/10.21831/jpe.v5i2.14510

\section{Introduction}

The success of 2013 Curriculum implementation will be heavily determined by the teachers as the curriculum executors in the field. Teachers as the avant-garde of the curriculum are expected to perform their tasks well. Teachers are demanded to be able to design the learning process according to the 2013 Curriculum. However, it is not easy to adjust ourselves to something new and it is in this adjustment stage that teachers start encountering problems in implementing the new curriculum.

One of the problems that have caused the implementation of 2013 Curriculum less maximum is the process of diffusion among the teachers as the curriculum executor in the field that has not run smoothly. Jimmy Paat in
Sindonews stated that "The case is that the change from the old curriculum to the 2013 Curriculum is too fast despite the government claim that they have reviewed the new curriculum (Fajardin, 2013). The 2013 Curriculum should have been implemented in 2015 so that teachers may prepare themselves first." Responding to the statement, the researcher agrees that the process of diffusion will run smoothly if teachers are provided with well-prepared training programs prior to the implementation 2013 Curriculum. The training period that has been very short is perceived insufficient by the teachers for understanding the spirit of 2013 Curriculum. Teachers as the main executor in the field should be well prepared in order that the 2013 Curriculum can be successfully implemented. 
Hidayat (2013, p. 114) mentioned that teachers should be positioned as the "main actor." Teachers should have good preparation, starting from lesson plan design, learning process conduct, assessment, analysis, until follow up. Paying attention to the previous statement, the researcher might conclude that the situation in the field does not go in accordance to the expectation and, as a result, gaps (problems) have appeared within the implementation of 2013 Curriculum. These gaps then cause subsequent problems due to the lack of preparation. The facts in the field show that many teachers who have not completely understood the 2013 Curriculum. This problem has been caused by the training period that has been too short and the learning process that should be directly conducted according to the new curriculum. Teachers are confused in designing the lesson plans, learning process conduct, and assessment toward the students.

The first problem that teachers perceive in the implementation of 2013 Curriculum is the lack of understanding in designing the lesson plan. 2013 Curriculum requires teachers to design learning process using the thematicintegrative model. Thematic learning is originally not a new matter for the elementary school teachers. In the Educational Unit Level Curriculum (KTSP, Kurikulum Tingkat Satuan Pendidikan), the thematic learning model had been implemented to the students of Grade I, II, and III; however, in the practice many teachers have not implemented the thematic learning well. Suyanto \& Djihad (2013, p. 180) stated that the thematic learning has more emphasis on the students' active involvement in the learning process so that they can attain direct learning experiences and can be trained to attain knowledge from the subjects that they are studying. From this statement, the researcher might conclude that using the thematic-integrative learning model is expected to turn the learning process to be more joyful and meaningful for the students. In addition to creating joyful and meaningful learning process for students, teachers are also required to design a learning process that integrates the character values and the sociocultural values around the students' environment. Unfortunately, the facts in the field show that the lesson plans that the teachers design still have inter-subject borders and, as a result, the thematic characters have not been apparent. Based on the researcher's analysis toward the sample of the lesson plans that have been designed, there has not been any clear integration toward the character values. In addition, the lesson plans that have been developed have not integrated the local sociocultural values as the values that should be developed among the students in order that the values of the local wisdom shall not disappear. The Province of Yogyakarta Special Region Government Regulation Number 4 Article 4 Year 2011 regarding the Order of Cultural Values mentions that the order of cultural values in Yogyakarta that should be preserved include: (1) spiritual religious order; (2) moral order; (3) societal order; (4) traditional order; (5) educational and scientific order; (6) technological order; (7) spatial layout and architectural order; (8) employment order; (9) art order; (10) linguistic order; (11) cultural heritage and cultural area order; (2) leadership and governance order; and (13) passion order (Gubernur Daerah Istimewa Yogyakarta, 2012). Based on this regulation, it can be understood that in the teaching-learning process teachers should not leave the cultural values that should be developed among the students according to the aspects that have been mandated. The introduction and the implementation of the cultural values in schools will help students to understand the governing cultural values in their region and the students are expected to be able to preserve the existing cultural values. The lesson plans and the learning media that the teachers implement in conducting their learning process should also contain the local sociocultural values. in relation to the learning media that will be implemented, based on the results of the interview the researcher has found that the use of learning media has been perceived less effective. The teachers state that the existing learning media have not supported the learning process. Therefore, specific learning media should be developed for the thematic-integrative learning process with adjustment to the themes that will be taught.

Another factor that has been equally important is assessment; through assessment teachers can measure how far students have been progressing. Miller, Linn, \& Gronlund (2013) stated, "Assessment in the classroom can serve four different purposes: placement, diagnostic, formative, and summative assessment." From the statement, it can be implied that there are four types of assessment namely placement assessment, diagnostic assessment, formative assessment, and summative assessment. How- 
ever, the assessment system that has been implemented in 2013 Curriculum is the authentic assessment.

Mardapi (2012, p. 167) proposed that authentic assessment is an activity of gathering information in order to identify an individual's situation. In other words, authentic assessment enables teachers to assess their students from multiple joyful and meaningful activities. From the results of the preliminary study, the researcher found that the problems in implementing the authentic assessment have still been the obstacles for the teachers. The design of the instrument that will be implemented has not been in accordance to the learning process that the teacher will conduct. Most of the teachers still refer to the assessment teacher that can be found in the teacher's book which has been issued by the government. Responding the problems that have previously been mentioned, there should be solutions as the panacea for these problems.

From the results of needs analysis in several schools that have implemented the 2013 Curriculum, the researcher finds that there have been teachers' needs toward the learning instrument that will be in accordance to the curriculum framework. Then, based on the results of a review toward the product that has been developed by the teachers of SD $\mathrm{N}$ Pujokusuman 1, the learning instrument that the teachers have developed still have weaknesses and have not been in accordance to the description of the curriculum framework. Furthermore, there have not been any integration of the first and the second competence within the learning process and the learning design still refers to the teacher's book. These findings are supported by the results of an interview toward one of the teachers:

"The development of the learning instrument has not been optimum because we have not had clear understanding. The reason is that we do not have sufficient training period and, as a result, our material absorption has not been maximum. Then, within the training process the instructors sometimes do not provide appropriate answers upon our confusion. Eventually, we can only develop the learning instrument according to our knowledge and try to enrich our knowledge by reading other sources."

Therefore, an thematic-integrative learning instrument that is in accordance to the
2013 Curriculum should be developed and this learning instrument should be able to creative effective and joyful learning environment for the students. Moreover, the sociocultural values should be integrated into each part of the learning process. Moral degradation and cultural values decrease has been causing the local values to be marginalized by the foreign cultures whereas the cultural values serve as the identity of the nation. The sociocultural based learning instrument can provide positive impacts to students; in addition to describing clearly the social values, the sociocultural base learning instrument also helps students to identify and to learn using the surrounding cultural media. The sociocultural base learning instrument turns the learning process in joyful and meaningful activity for students because the learning media and sources come from their environment. This statement is supported by Sutarno (2007, p. 72) who stated that in cultural base learning process culture is integrated as a learning process tool for motivating students to apply knowledge, to work cooperatively, and to perceive intersubject associations. Therefore, it can be understood that using the sociocultural base learning process will be very helpful for helping students to understand the materials that they will learn.

Sutarno (2007, p. 72) explained that the use of local (ethnic) culture in learning process is very beneficial for the contemplation of learning process and results because students attain contextual learning experiences and apperception materials in order to understand the concept of science within the local (ethnic) culture that they have. As a result, learning process will make students always understand the values of surrounding culture as the identity of the nation when the values of the local cultures start being marginalized due to the globalization. Therefore, the researcher would like to develop the sociocultural base thematicintegrative learning instrument on the theme "My Aspiration" for the students of SD Negeri Pujokusuman 1. In addition to having been wellknown as the City of Students, the City of Yogyakarta has also been well known as the City of Cultures; so, it will be interesting to integrate the local cultures of tis city into the learning process.

\section{Method}

This study was a research and development. Sukmadinata $(2005$, p. 184$)$ proposed that 
in general the steps of research and development study consisted of three stages namely: (1) preliminary study; (2) model development; and (3) model testing and results socialization. The overall steps of the study that had been proposed became the guideline in conducting this study.

Throughout this study, the researcher would develop a learning instrument in the form of syllabus, lesson plan, learning media, and learning results assessment. The form of the learning instrument then would be the sociocultural base integrative thematic learning instrument and this learning instrument would be applied to the learning process for the elementary school students in the Province of Yogyakarta Special Region.

This research and development study would be conducted from May to August 2014 in Sekolah Dasar Negeri Pujokusuman 1 Yogyakarta. The subjects who would be involved in this study were the students from the state elementary school namely Sekolah Dasar Negeri Pujokusuman 1 Yogyakarta. The sample for this study would be randomly selected in order to provide the equal opportunity for the students to be selected as the subjects in this study. Then, the number of the students who would be involved was 112 people.

In general, there were three stages that the researcher designed in conducting this study namely preliminary study, model development, and also testing and socialization. The preliminary study consisted of data gathering activities as the basis of the product development. Then, in the preliminary product development the product would be validated and would undergo experiment from the limited scale to the expanded scale. Last but not the least, in the testing and socialization stage the product that had been resulted from the experiment would be put into a wider experiment in order to measure the effectiveness of the product namely the learning instrument that had been developed.

Data, Instrument, and Data Gathering Technique

The technique in this study was associated to the manners or the methods that had been implemented in the data gathering process. Then, the data gathering techniques that the researcher employed in this study were observation, interview, and questionnaire.

The interview was a technique of gathering data by asking a series of questions to the respondents or the sources. This interview technique was employed in the preliminary study in which the interview was intended to uncover information related to the implementation of 2013 Curriculum and its problems.

The observation was a technique of gathering data by observing the activities that had been taking place both participatory and non-participatory. This observation technique was employed during the preliminary study and the product experiment in the development stage. The instrument that the researcher used in conducting the observation was the Check List.

The questionnaire was a technique of gathering data indirectly by distributing the questionnaire. This questionnaire contained a series of questions or statements related to the sociocultural base integrative thematic learning instrument that had been developed and the implementation of this learning instrument.

The data gathering instruments in this study were employed in order to gather the data from the preliminary study, the model development, and until the operational testing. In the preliminary study, the instrument that had been employed was the interview guideline sheet. Then, in the product development stage the instrument that had been employed was the product feasibility assessment sheet for assessing the learning instrument that had been developed. This instrument was employed in the preliminary test, the main test, and the field operation test.

In the preliminary test, the researcher made use of the learning instrument assessment questionnaire. In the main test, the researcher made use of the learning instrument assessment questionnaire and the learning implementation observation sheet. Last but not the least, in the field operation test the researcher made use of pretest and posttest items, the observation sheet, and the questionnaire. The instrument that had been developed was validated using the content validity.

\section{Data Analysis Technique}

The data that had been attained from the interview guideline, the product assessment sheet, the observation sheet, and the questionnaire were analyzed using the descriptive statistics and the quantitative statistics. The qualitative data were in the form of comments and suggestions that had been gathered from the material expert, the evaluation expert, the practitioner, and the colleague. Then, the results of observation were analyzed and were described qualitatively in order to revise the 
product that had been developed. On the other hand, the quantitative data were in the form of assessment score that had been provided by the material expert, the evaluation expert, the practitioner (the elementary school teachers), and the colleagues using the learning evaluation instrument.

The data analysis technique for the learning instrument feasibility was the calculation of total mean score from each component and the formula of this calculation would be provided as follows:

$$
\mathrm{X}=\frac{\sum x}{n}
$$

(Sugiyono, 2010, p. 49)

Note:

$\mathrm{X}=$ mean score

$\sum \mathrm{x}=$ total score

$\mathrm{n}=$ number of rater

The score then would be converted into three-scale value with three options namely very good (3), good (2), and poor (1). According to Sukardjo, (2010, p.1) the score that had been attained should be converted into the three-scale qualitative data (the interval data) with following requirements.

Table 1. Conversion from the Mean Score Interval into the Criteria on the Sociocultural Base Integrative Thematic Learning Instrument

\begin{tabular}{clc}
\hline Score & \multicolumn{1}{c}{ Score Interval } & Category \\
\hline A & $X>X_{i}+1,8 \mathrm{Sbi}$ & Very Good \\
B & $X_{i}+0,6 \mathrm{SBi}<\mathrm{X} \leq \mathrm{X}_{\mathrm{i}}+1,8 \mathrm{SBi}$ & Good \\
C & $\mathrm{X}_{\mathrm{i}}-0,6 \mathrm{SBi}<\mathrm{X} \leq \mathrm{X}_{\mathrm{i}}+0,6 \mathrm{SBi}$ & Moderate \\
$\mathrm{D}$ & $\mathrm{X}_{\mathrm{i}}-1,8 \mathrm{SBi}<\mathrm{X} \leq \mathrm{X}_{\mathrm{i}}-0,6 \mathrm{SBi}$ & Poor \\
E & $\mathrm{X} \leq \mathrm{X}_{\mathrm{i}}-1,8 \mathrm{Sbi}$ & Worse \\
\hline
\end{tabular}

Note:

Xi: Mean/ideal mean score $=$

$1 / 2$ (maximum score + minimum score)

Sbi: Ideal standard deviation $=$

$1 / 6$ (maximum score - minimum score)

$\mathrm{X}$ : Skor yang diperoleh.

\section{Results and Discussions}

Preliminary Study

Based on the results of field survey, the researcher found the following problem: the sociocultural base learning has not been implemented intensively. The teachers do not have clear understanding toward the 2013 Curriculum. Such unclear understanding is caused by the insufficient training period; as a result, within the implementation of 2013
Curriculum the teachers are demanded to develop their skills independently through both library studies and discussion with their colleagues.

The teachers also have difficulties in developing the learning instrument such as lesson plans, learning media, and especially evaluation/assessment instrument. In implementing the new curriculum, the teachers are demanded to perform the integrative thematic learning process through the lesson plan that they develop. In the same time, the teachers also have difficulties in developing the sociocultural base learning media. Sometimes the learning media have been socioculturally based but it has not been implemented intensively.

Last but not the least, the researcher still has difficulties in developing the evaluation instrument. The evaluation system of 2013 Curriculum applies the authentic assessment. The use of this assessment type enables the teachers to evaluate the students' preparedness, the learning process, and the learning results holistically. In order to perform this authentic assessment, there should be practical and userfriendly assessment tool for the teachers. This situation becomes worse due to the lack of sources that may serve as references in implementing the learning process under 2013 Curriculum.

Development

The development stage consists of two parts namely preliminary field testing and main field testing. The preliminary field testing is conducted after the draft of the product has been designed and has been tested by the experts and the practitioners. On the other hand, the main field testing is conducted after the test toward the draft of the product has been finished by the experts.

Based on the results of the learning instrument feasibility assessment, the researcher may conclude that all of the components in the learning instrument, namely the syllabus, the lesson plan, the learning media, and the learning results assessment, have belonged to the " $A$ " category. Therefore, this instrument is feasible for the test.

After the product has been stated feasible for the test, the researcher then conducts the main field testing. From the results of the main field testing, the researcher may conclude that the teachers have performed the learning process well using the learning instrument that has been 
developed. The results of the observation toward the learning process will be provided as follows.

Table 2. Results of Teacher Observation

\begin{tabular}{clrc}
\hline No. & Observation & Mean & Note \\
\hline 1. & First Day & 0.70 & Well Implemented \\
2. & Second Day & 0.85 & Well Implemented \\
3. & Third Day & 0.85 & Well Implemented \\
4. & Fourth Day & 0.90 & Well Implemented \\
5. & Fifth Day & 0.95 & Well Implemented \\
\hline
\end{tabular}

Moreover, from the aspect of the students' activities, the learning process that has been performed is already in accordance to the concept of sociocultural base learning. The evidence of this statement can be seen in the following table.

Table 3. Results of Student Observation

\begin{tabular}{clrl}
\hline No. & Observation & Mean & \multicolumn{1}{c}{ Note } \\
\hline 1. & First Day & 7.25 & In Accordance \\
2. & Second Day & 7.39 & In Accordance \\
3. & Third Day & 7.36 & In Accordance \\
4. & Fourth Day & 7.32 & In Accordance \\
5. & Fifth Day & 7.36 & In Accordance \\
\hline
\end{tabular}

Based on the results in the above table, the researcher finds that the students' activities have been in accordance to the sociocultural values. This can be seen from the mean of the observation results, which have been greater than 7.00. In other words, most of the requirements for the concordance to the sociocultural values-based learning process have been met.

Moreover, based on the students' posttest scores during the main field testing the researcher finds the following results:

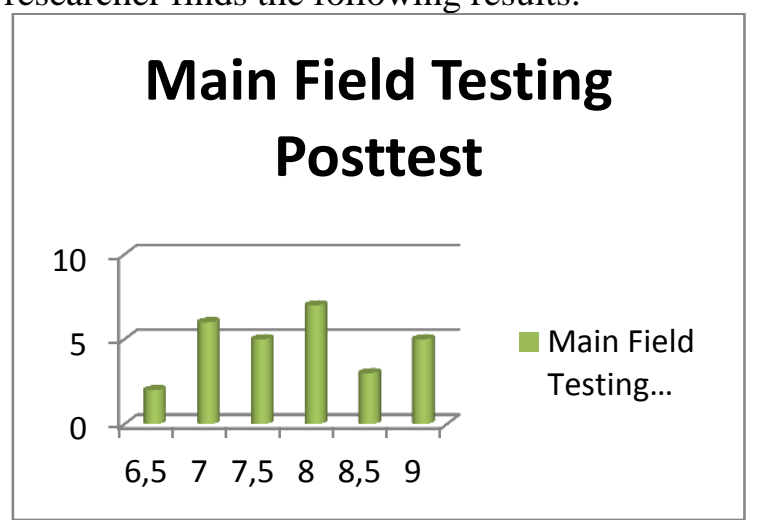

Figure 1. Diagram of Students' Posttest Scores in the Main Field Testing

From the above graphic, it can be implied that most of the students have achieved the cut score namely 6.50 . The achievement of this cut score then becomes the basis for performing further testing in the following stage.
Testing and Socialization

After the main field testing has been performed and the product has been revised based on the provided feedback, the test activities are progressed to the operational field testing. The results from the field operational testing are as follows:

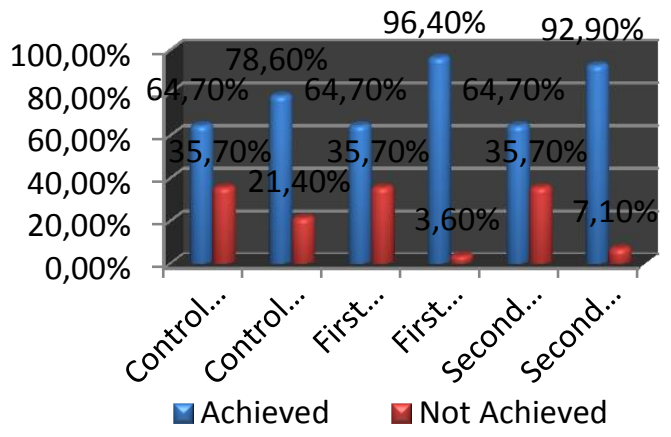

Figure 2. Diagram of Comparison on the Percentage of Students' Cut Score Achievement

Based on the above diagram, the researcher may conclude that the percentage of the students' cut score achievement in the experimental group has been higher than that in the control group. The improvement on the percentage of the control group is $14.30 \%$, while the improvement on the percentage of the first experimental group is $31.70 \%$ and of the second experimental group is $28.20 \%$. Such improvement displays that the learning process using the sociocultural base integrative thematic learning instrument that has been applied o the experimental group is more effective.

In addition to having been viewed from the percentage of the students' cut score achievement, the effectiveness test of the learning instrument that has been developed is also conducted using the differential test. From the results of the differential t-test, the researcher has the following findings: the independent $t-$ test calculation in the first comparison on the students' cut score achievement shows that the F value is 0.128 with significance level 0.575 , while the independent t-test calculation in the second comparison on the students' cut score achievement shows that the $\mathrm{F}$ value is 0.318 with significance level $0.575 \geq 0.050$. These findings imply that the variance on the comparison of the students' cut score achievement between the control group and also the first and the second experimental group is equal. In this test, the researcher makes use of the same variance (equal variance assumed). The above diagram also implies that the $t$ value of the same 
variance in the first comparison is 3.652 with significance level 0.001 and in the second comparison is 3.154 with significance level 0.001 . Because the significance is lower or equal to 0.050 , the $\mathrm{H}_{0}$ is rejected. Based on this statement, the researcher may conclude that there has been significance difference on the students' learning results between the students who have been treated using the sociocultural base integrative thematic learning instrument and the students who have been treated using the conventional learning instrument.

\section{Conclusions}

The first conclusion is related to the syllabus of the sociocultural base integrative thematic learning instrument on the theme "My Aspiration" that has been applied to the students of SD N 1 Pujokusuman. According to the syllabus expert, the product's score is 41 out of 45 with the "A" title. Therefore, the syllabus belongs to the "Very Good" category.

The second conclusion is related to the lesson plan of the sociocultural base integrative thematic learning instrument on the theme "My Aspiration" that has been applied to the students of SD N 1 Pujokusuman. According to the lesson plan expert, the product's score is 69 out of 45 with the "A" title. Therefore, the lesson plan belongs to the "Very Good" category.

The third conclusion is related to the learning media of the sociocultural base integrative thematic learning instrument on the theme "My Aspiration" that has been applied to the students of SD N 1 Pujokusuman. According to the learning media expert, the product's score is 28 out of 30 with the "A" title. Therefore, the syllabus belongs to the "Very Good" category.

The fourth conclusion is related to the learning results test of the sociocultural base integrative thematic learning instrument on the theme "My Aspiration" that has been applied to the students of SD N 1 Pujokusuman. According to the learning results test expert, the product's score is 15 out of 18 with the "A" title. Therefore, the syllabus belongs to the "Very Good" category.

From the percentage of the students' cut score achievement, this learning instrument has higher effectiveness. It is able to encourage $96.40 \%$ students in the first experimental group and $92.90 \%$ students in the second experimental group to achieve the cut score. Then, from the results of the differential test between the control group and the experimental group it is apparent that there has been significant difference between the learning results of the students in the control group and those of the students in the experimental group.

The learning instrument that has been developed is expected to be employed by the teachers in order to develop sociocultural base interaction among the students in the elementary school. The learning instrument that has been developed can serve as a model (guideline) in developing similar instruments with different themes. Then, the learning instrument that has been developed can also be applied as a blueprint for both other teachers and other schools. Teachers can change, add, or even reduce the content in this learning instrument in order to be more appropriate to the students' conditions.

\section{References}

Fajardin, M. A. (2013). Pengamat: pelaksanaan Kurikulum 2013 akan gagal. Retrieved August 10, 2017, from https://nasional.sindonews.com $/ \mathrm{read} / 7614$ 45/15/pengamat-pelaksanaan-kurikulum2013-akan-gagal-1373922793

Gubernur Daerah Istimewa Yogyakarta. Peraturan daerah Provinsi Daerah Istimewa Yogyakarta nomor 4 tahun 2012 tentang perlindungan dan pemenuhan hak-hak penyandang disabilitas, Pub. L. No. 4, Pemerintah Provinsi Daerah Istimewa Yogyakarta (2012).

Hidayat, S. (2013). Pengembangan kurikulum baru. Bandung: Remaja Rosdakarya.

Mardapi, D. (2012). Pengukuran penilaian dan evaluasi pendidikan. Yogyakarta: Nuha Medika.

Miller, M. D., Linn, R. L., \& Gronlund, N. E. (2013). Measurement and assessment in teaching. New Jersey: Pearson.

Sugiyono. (2010). Metode penelitian pendidikan: Pendekatan kuantitatif, kualitatif, dan $R \& D$. Bandung: Alfabeta.

Sukmadinata, N. S. (2005). Pengembangan kurikulum: teori dan praktek. Bandung : Remaja Rosdakarya. https://doi.org/2005

Sutarno, S. (2007). Pendidikan multikultural. Jakarta: Direktorat Jenderal Pendidikan Tinggi Departemen Pendidikan Nasional.

Suyanto, S., \& Djihad, A. (2013). Bagaimana menjadi calon guru dan guru profesional. Yogyakarta: Multi Pressindo. 